International Journal of Environment, Agriculture and Biotechnology
Vol-7, Issue-1; Jan-Feb, 2022
JUEAB
Journal Home Page Available: $\underline{\text { https://ijeab.com/ }}$
Journal DOI: $10.22161 /$ ijeab

Peer Reviewed

\title{
Micronutrients and Fertilizers for Improving and Maintaining Crop Value: A Review
}

\author{
Anil K. Yadav ${ }^{1}$, Gaurav G. Gurnule ${ }^{2}$, Nikita I. Gour ${ }^{3}$, Uma There ${ }^{4}$, Vikas C. Choudhary ${ }^{5}$ \\ 1,3,4,5 Rural Chemical Division, Mahatma Gandhi Institute for Rural Industrialization, Wardha, Maharashtra, India. \\ ${ }^{2}$ Bajaj College of Science, Wardha, Maharashtra, India. \\ Corresponding author: anil0202@gmail.com
}

Received: 19 Dec 2021; Received in revised form: 01 Feb 2022; Accepted: 09 Feb 2022; Available online: 16 Feb 2022

(C)2022 The Author(s). Published by Infogain Publication. This is an open access article under the CC BY license

(https://creativecommons.org/licenses/by/4.0/).

\begin{abstract}
The effect of mineral and organic fertilization on the contents of $\mathrm{Fe}, \mathrm{Cu}, \mathrm{Zn}, \mathrm{Mn}, \mathrm{B}$, and $\mathrm{Mo}$ in soil and the dirt solution just as on accessibility of these elements for crops were researched in the drawnout preliminary. The most elevated contents of $\mathrm{Zn}, \mathrm{Fe}, \mathrm{Mn}$, and $\mathrm{Cu}$ in soil and soil solution were seen in the treatment with the least $p H(N P K)$. In this equivalent mix, the substance of $B$ and Mo was the least. On the convergence of $\mathrm{Zn}, \mathrm{B}$, and $\mathrm{Fe}$ in the dirt solution, significantly expanded under farmyard manure application. Natural fertilizers provide the normal and physical activities of the soil but contain very few supplements, so more are needed to improve plants. Plant take-up of nutrients can continue when they are available in a plant-accessible structure. Much of the time, nutrients are caught up in an ionic structure from (or along with) soil water. Even though minerals are the beginning of most nutrients, and most supplement components in the dirt are held in a glasslike structure inside essential and optional minerals, the climate is too leisurely to help quick plant development. For instance, the use of finely ground minerals, feldspar, and apatite, to soil rarely gives the fundamental measures of potassium and phosphorus at a rate adequate for great plant development, as a large portion of the nutrients stays bound in the precious stones of those minerals.
\end{abstract}

Keywords-organic, nutritious, mineral, micronutrients, fertilizer.

\section{INTRODUCTION}

There is a continuous discussion regarding the general benefits and burdens of organic cultivating contrasted with conventional cultivating. At the focal point of the issue is the utilization of organic supplement sources like creature manures, plant deposits, and bio-solids versus made (mineral) compost sources. While the goal of the general discussion, including organic and inorganic, still needs to be found, crop inclination for supplement sources is guaranteed. Crops take up (assimilate) and utilize only inorganic supplement structures. Every one of the nutrients contained in any organic source stays inaccessible for crop use until the material is deteriorated (mineralized), delivering its nutrients to the inorganic soil pool. While organic substances are found somewhat in every agrarian soil, they are consistently in some phase of change mineralization or decay - back to the inorganic structure.
They are significant supplement sources. However, the nutrients they contain should be changed to their inorganic structure to be taken up by plants.

Seventeen elements, or nutrients, are fundamental for plant development and generation. They are carbon (C), hydrogen $(\mathrm{H})$, oxygen $(\mathrm{O})$, nitrogen $(\mathrm{N})$, phosphorus $(\mathrm{P})$, potassium $(\mathrm{K})$, sulfur $(\mathrm{S})$, calcium $(\mathrm{Ca})$, magnesium $(\mathrm{Mg})$, iron $(\mathrm{Fe})$, boron $(\mathrm{B})$, manganese $(\mathrm{Mn})$, copper $(\mathrm{Cu})$, zinc $(\mathrm{Zn})$, molybdenum (Mo), nickel (Ni) and chlorine $(\mathrm{Cl})$ (Kumar, S. (2013).Nutrients needed for plants to finish their life cycle are viewed as fundamental nutrients. Nutrients that upgrade plants' development but are not important to finish the plant's life cycle are viewed as superfluous. Except for carbon, hydrogen, and oxygen, which are provided via carbon dioxide and water, and nitrogen given through nitrogen obsession, the nutrients get initially from the mineral part of the dirt. The Law of the Minimum 
communicates that when the accessible type of a supplement isn't insufficient extent in the dirt arrangement, then, at that point, different nutrients can't be taken up at an ideal rate by a plant. A specific supplement proportion of the dirt arrangement is along these lines required for streamlining plant development, a worth which may contrast from supplement ratios determined from plant synthesis.

\section{Micronutrients History}

Micronutrients are the essential elements needed by plants in somewhat low concentrations. Micronutrients structure an intelligence gathering, including eight center elements: Iron $(\mathrm{Fe})$, Sodium $(\mathrm{Na})$, Chlorine $(\mathrm{Cl})$, Boron $(\mathrm{B})$, Manganese (Mn), Zinc (Zn), Copper (Cu), and Molybdenum (Mo). A few scientists think about silicon (Si) as a micronutrient. However, it is not known to be essential, it is collected by plants and utilized in the plant body at a genuinely high focus. Cobalt (Co) is an essential micronutrient for plant species that structure root nodules. Additionally, nickel (Ni) is a micronutrient that, while essential, is virtually never limited or lacking in the natural world. In the uncommon situations when it is limited, indications of decrease in leaf size, measuring of the leaf, and diminished vegetative development. When developed without nickel, plants neglect to deliver urea's in adequate quantity and can endure the impacts of accumulating toxic amounts of urea in the cells (Mengal et.al., 2001)
Table 1: Difference between organic and inorganic compounds.

\begin{tabular}{|l|l|}
\hline Organic & Inorganic \\
\hline $\begin{array}{l}\text { Large non-nutrient } \\
\text { content. }\end{array}$ & $\begin{array}{l}\text { High concentration of } \\
\text { nutrients. }\end{array}$ \\
\hline Bulky. & Ease of transport. \\
\hline Little direct cost. & Increasing cost. \\
\hline $\begin{array}{l}\text { Imprecise content } \\
\text { analysis. }\end{array}$ & Made from finite resources. \\
\hline $\begin{array}{l}\text { No direct energy use in } \\
\text { manufacture. }\end{array}$ & $\begin{array}{l}\text { Large direct energy use in } \\
\text { manufacture. }\end{array}$ \\
\hline Readily available. & $\begin{array}{l}\text { Availability depends on } \\
\text { production, cost, and region. }\end{array}$ \\
\hline $\begin{array}{l}\text { Provides disposal of } \\
\text { wastes. }\end{array}$ & $\begin{array}{l}\text { Creates wastes in processing, } \\
\text { but can also utilize wastes } \\
\text { from other manufacturing } \\
\text { processes. }\end{array}$ \\
\hline Source: Stout (1984). & \multicolumn{2}{|l}{} \\
\hline
\end{tabular}

Filling outside in field soil will see the most advantage from utilizing organic nutrients. This is the place where the microorganisms are at their best, working with organic mixtures from soil amendments and insoluble minerals normally happening in the dirt. The nutrients can separate gradually and feed the plant as it needs. Inorganic amendments can give extra sustenance, and when applied moderately, won't hurt soil creatures and ought to address any likely supplement deficiencies.

Table 2: Chemical Fertilizer vs Organic Fertilizer Comparison Chart.

\begin{tabular}{|c|c|c|}
\hline & Chemical Fertilizer & Organic Fertilizer \\
\hline Example & $\begin{array}{l}\text { Ammonium sulfate, superphosphates, } \\
\text { ammonium nitrate, urea, ammonium } \\
\text { chloride, etc. }\end{array}$ & $\begin{array}{l}\text { Cottonseed meal, blood meal, fish emulsion, } \\
\text { manure, sewage sludge, etc. }\end{array}$ \\
\hline Advantages & $\begin{array}{l}\text { Chemical fertilizers contain the three } \\
\text { primary macronutrients that provide an } \\
\text { immediate supply of nutrients; may also } \\
\text { contain secondary macronutrients and trace } \\
\text { minerals. }\end{array}$ & $\begin{array}{l}\text { Adds natural nutrients to the soil. Increased soil } \\
\text { organic matter improves soil structure, improves } \\
\text { water holding capacity, reduces soil crusting } \\
\text { problems, provide a slow release of nutrients. }\end{array}$ \\
\hline Disadvantages & $\begin{array}{l}\text { Several chemical fertilizers have high acid } \\
\text { content. They can burn the skin. Changes soil } \\
\text { fertility. }\end{array}$ & $\begin{array}{l}\text { Have slow-release capability; distribution of } \\
\text { nutrients in organic fertilizers is not equal }\end{array}$ \\
\hline $\begin{array}{l}\text { Rate of } \\
\text { Production }\end{array}$ & Immediate supply or slow release. & Slow release only. \\
\hline About & $\begin{array}{l}\text { Chemical fertilizers are manufactured from } \\
\text { synthetic or inorganic materials. }\end{array}$ & $\begin{array}{l}\text { Organic fertilizers are made from materials } \\
\text { derived from living things or inorganic minerals. }\end{array}$ \\
\hline
\end{tabular}




\begin{tabular}{|l|l|l|}
\hline Nutrients & $\begin{array}{l}\text { Have equal distribution of three essential } \\
\text { nutrients: phosphorus, nitrogen, potassium }\end{array}$ & Have unequal distribution of essential nutrients \\
\hline Cost & $\begin{array}{l}\text { Chemical Fertilizers turn out to be cheaper } \\
\text { because they pack more nutrients per pound } \\
\text { of weight }\end{array}$ & $\begin{array}{l}\text { Organic fertilizer may be cheaper per pound but } \\
\text { works out to be more expensive overall because } \\
\text { more of it is needed for the same level of nutrients }\end{array}$ \\
\hline Sourcen
\end{tabular}

Source: Lal, R. (2006), Matsumoto, T. and Yamano, T. (2009), Alimi, T., et al., (2007), Abedi, T. et al., (2010).

\section{ORGANIC DEFINITION AND SOURCING}

The straightforward meaning of organic is "comprising of or got from living matter." According to the National Organic Program (NOP), "organic is a naming term for food or other agrarian items that have been created utilizing social, natural, and mechanical practices that help the cycling of on-ranch assets, advance ecological equilibrium, and monitor biodiversity as per the USDA organic guidelines. This implies that organic tasks should keep up with or upgrade soil and water quality, while additionally monitoring wetlands, forests, and untamed life." Soil organic matter alludes to all parts that are of natural beginning including decaying plant material and creature squanders, soil microorganisms and the substances orchestrated by the dirt microbiome. Organic matter adds to pools of plant accessible nutrients through a progressive breakdown of materials. In the event that depending totally on organic matter in the soil for nutrients, plants may not get sufficient nourishment to give ideal yields and quality. This is the place where soil amendments, or composts, assume a significant part.

Unrefined components for organic manures are largely obtained from creature manures, creature results, rural and metropolitan human waste, fertilizer, and yield build-up. Creature side-effects incorporate new or treated soil excrement, worm castings, bat guano, bone dinner, feather feast, and fish supper. The plant determined amendments to incorporate kelp supper, hay feast, and soybean dinner. Town/metropolitan fertilizer is produced using modern waste, city trash, sewage ooze, and so on. Rural fertilizer is produced using straw, leaves, domesticated animals, bedding and compost, creature delivering material, plant squander material, and so forth (Mortved, J.J.,1991).

Table 3: Average nutrient content of bulky organic manures and composts.

\begin{tabular}{|l|l|l|l|l|l|l|}
\hline \multirow{2}{*}{$\begin{array}{l}\text { Sr. } \\
\text { no. }\end{array}$} & \multirow{2}{*}{$\begin{array}{l}\text { Manures/ } \\
\text { Composts }\end{array}$} & \multirow{2}{*}{ C: $\mathbf{N}$ ratio } & \multicolumn{2}{|l|}{ Nutrient content (\%) } & \multirow{2}{*}{ Reference } \\
\cline { 3 - 6 } & & $\mathbf{N}$ & $\mathbf{P}_{\mathbf{2}} \mathbf{O}_{\mathbf{5}}$ & \multicolumn{2}{|l|}{$\mathbf{K}_{\mathbf{2}} \mathbf{O}$} & \\
\hline 1 & Farmyard manure & $1: 25-40$ & 0.80 & 0.41 & 0.74 & Palaniappan (2010) \\
\hline 2 & Vermicompost & $1: 16.8$ & 1.20 & 0.004 & 0.37 & Jambhekar (1992) \\
\hline 3 & $\begin{array}{l}\text { Cattle waste } \\
\text { Vermicompost }\end{array}$ & $1: 8.32-19.20$ & $0.51-1.61$ & $0.19-1.02$ & $0.15-0.73$ & $\begin{array}{l}\text { Nagavallemma et al. } \\
\text { (2004) }\end{array}$ \\
\hline 4 & $\begin{array}{l}\text { Palm oil waste based } \\
\text { Vermicompost }\end{array}$ & $1: 13.23-32.72$ & $1.29-2.53$ & - & $7.79-11.97$ & Rupani et al. (2013) \\
\hline
\end{tabular}

\section{INORGANIC DEFINITION AND SOURCING}

The meaning of inorganic is something contrary to organic: "not comprising of or got from living matter." Inorganic engineered or mineral aggregate terms are used to depict compost that isn't gotten from living or natural matter. Minerals can in any case be viewed as characteristic info, while engineered composts contain minerals that are adjusted during assembling to deliver a got done, more compelling item. These alterations are fundamental to make an item that has more noteworthy solvency, soundness, and plant-take-up proficiency.
The utilization of inorganic manures enjoys benefits in the weed business relying upon the administration and development style utilized. When filling in holders, indoor and nursery spaces will benefit incredibly from the utilization of mineral-based manures because of the high degree of supplement accessibility from this kind of treatment. Quickly developing annuals require fast nourishment, and the ionic type of elements given by mineral nutrients precisely conveys that.

The wellspring of unrefined components can have an effect, particularly when developing weed. We realize that weed is a gatherer of weighty metals, which implies that it can ingest and hold poisons from its developing climate at a lot more 
significant levels than other plant species. Modest, modern grade minerals might be sullied with undeniable degrees of harmful weighty metals, like cadmium or mercury. Further handling to a greater grade, for example, drug grade, will extraordinarily diminish or dispense with (contingent upon the interaction) the levels of these foreign substances, guaranteeing safe end-shopper use (Mortved, J.J., 1991).

\section{COMPARISON OF INPUTS}

Customary organic sources of information, regularly provided as crude minerals, fertilizer, and manures, can be hard to depend on and may not supply satisfactory plant sustenance. The supplement accessibility of organic sources is generally shifted and just gives negligible accessibility in the primary year of utilization. All things considered, extreme inorganic manure application might be unsafe for the variety of soil organic entities and soil structure. Consolidating asset information sources might conceivably deliver ideal outcomes, particularly if filling in soil.

The Journal of Agronomy distributed examination discoveries that dirt's treated with inorganic manures versus organic composts had more elevated levels of organic carbon, N, P, K, microorganisms, and parasites than soils that were untreated. Indeed, the supplement levels were higher than in the organic plots, and the natural life forms were higher than in the untreated plots. This infers that, as opposed to prevalent thinking, inorganic composts don't kill living beings, and truth be told, offer an extra food hotspot for soil science and further add to soil fruitfulness.

The expansion of mineral composts to compost and even to manures can expand the impact of these amendments on organic $\mathrm{C}$ and $\mathrm{N}$ content in soil and soil compound activities. Complete supplement manure applications might deal with existing supplement deficiencies when applied at the right time in the plant's life cycle. Without even a trace of being able to test soil consistently for supplement status, applying inorganic composts all through the harvest cycle is a sensible choice to guarantee ideal yield and quality.

The lower response of rice crops to the application of fertilizer additives, including mulch, could be attributed to the emerging shortage of supplements due to the current horticultural era and insufficient or unbalanced use of excrement. It is logical to observe around the world that compounds $\mathrm{N}, \mathrm{P}$ and $\mathrm{K}$ alone are generally not sufficient to provide modified feeds with ideal rice yields and qualities, and attention should also be paid to the use of discretionary components and micronutrients. Distinguishing the western UP from Punjab to the north and Tamil Nadu to the south, the extent of use of $\mathrm{N}: \mathrm{P}_{2} \mathrm{O}_{5}: \mathrm{K}_{2} \mathrm{O}$ in the western UP beyond Punjab is much broader when it diverges from Tamil Nadu, showing that the greater the Fertilizer consuming states have the best imbalance when taking supplements. The main clarification of the range of products in the areas of fertilizer use in the north and south is the result of changes in soil and plan. About $35 \%$ of all manure in India is consumed with rice (ICAR Annual Report 2019-20).

The improvement of auxiliary varieties with high yield and open to fertilizers and water scaffolding, with the concentrated management of subsequent green alterations with prolonged and excessive use of inorganic fertilizers, has impoverished the intrinsic richness of the soil. The deterioration or stagnation of performance is attributed to the addition of mining activity and the reduced use of organic matter. Some large surveys in India showed a decrease in rice control due to the constant use of chemical fertilizers.

The Coordinated Complement Board (INM-Integrated Nutrient Management) also plans to promote the wellness of the flat and support crucial levels of comfort and creation. On the floor, in any case, the limited availability of FYM provides an excellent basis for its use as a dietary supplement. Sharma, (2012), defines the extended yields and benefits of using food supplements on rice with organic products. Organics provide a supplement in the peak maintenance season and provide a small supplement, modifying the actual soil lead in the same way that increases the capacity of applied supplements. Income in the foreground has increased development. In contrast to the poorly organized effects of inorganic fertilizers, natural wastes are collected locally, further promoting the wellbeing of the soil and resulting in better yields. However, it is unlikely that the use of natural fertilizers will only cover the essential components of the plant, as it contains relatively small amounts of supplements. To provide the soil with all the plant additives in the snap design and keep up with the incredible well-being of the soil, it is also essential to use natural fertilizers in combination with inorganic compost to achieve optimal yields.

Nitrogen is the basic supplement, and various natural and inorganic nitrogen sources have a fundamental effect and a decisive influence on the texture of the rice grain. Adding built-in bio, organic, and complex fertilizers to the table can further promote competition and the nature of the rice grain. Organic fertilizers alone or mixed with natural fertilizers work within the quality limits of fragrant rice.

Dixit and Gupta, 2000; Quyen and Sharma, 2013. Recovery of overhead rice and solvent value of flavoured rice varieties treated for the use of agricultural residues. The lower natural fertilizer segments continued to favour quality limits such as peeling, handling, and harvesting the rice tips compared to the higher measurements.

Saha et al., (2017) Handling, and recovery of rice from the head, length, and length of the wick: the extension of the 
width immediately after cooking the rice has changed even when using natural waste mixed with inorganic material.

Wheat (Triticumaestivum L.), called "oat head", belongs to the Poaceae (Gramineae) family. Globally and publicly, wheat is the second most important food crop after rice and contributes approximately $35 \%$ of the public food budget. In India, the normal public value of $3,200 \mathrm{~kg} / \mathrm{ha}$ is produced in an area of 30.78 million hectares with a production of 98.51 million tons. In Haryana, wheat was produced on an area of 2,558 lakh ha with a production of 11,546.81t lakh and an ordinary productivity of $4,514 \mathrm{~kg} / \mathrm{ha}$, well above the public average.

As India's Green Revolution approached in the 1960s, grain production and use grew to undeniable levels, achieved through the use of high-yield assortments, high doses of synthetic fertilizers, pesticides, and heavy agricultural products. Motorized, which caused considerable stress in our regular asset base.

Charyulu and Biswas, (2015), The constant use of artificial fertilizers, agro-artificial materials, and various practices were extremely prudent, which led to food supplements being diverted significantly more than their recovery and, in addition, reduced physical, material, and natural properties and, finally, reduced fertility and dirt efficiency. The absurd use of artificial substances has led to problems of animal and human protection due to the continuous evolution of food. The developments that have occurred have also damaged profitable soil fauna and microorganisms (nightcrawlers) and worsened soil fertility.

In this way, recently developed practices have changed and natural agriculture has become a good option for affordable agribusiness. The declining utility of factors, general energy crises, have driven the current emphasis on supplementing or replacing inorganic fertilizers with neglected food sources such as natural fertilizers and manure.

(Prasa, 2015). To improve agricultural value, the positive soil content in the soil must be kept constant through repeated use of natural changes and proper management practices.

(Lodhiet al., 2016). The use of natural food supplements for agricultural production can help achieve acceptable longterm agricultural efficiency. Expansion of natural matter through the use of natural fertilizers and manure also creates regular, technical, and physical properties of the soil that provide superior efficiency. Natural processing increases the natural carbon content of the soil, which is believed to be most useful for further improvement and performance of grain components.

Indian agriculture was all about cows in old-fashioned events. The goal is to create design-centric development system models that are acceptable even today. Some experts use the intricacies of natural cow manure and urine supplements as a source for herbal supplements. Definitions of cow-based food supplements such as Jivamrit, Ghanjivamrit and Beejamrit to create an extension of the small fauna and vegetation of the soil that further promotes the fertility status of the land Jivamrit's commitment to long-term effects was illustrated by integrated nutrient management in the soybean and wheat management system. Various sources such as Ghanjivamrit and SaptDhanyaAnkur Ark are used as additional focal points for purely natural grain production. The precious creatures' relationship with jivamrit and ghanjivamrit transforms food supplements of inaccessible design into those available when applied on land. The current research aimed to examine the effect of natural dietary supplements in enhancing pimples (Loura et al., 2020).

\section{OBJECTIVE}

1. Agricultural inventory of organic and inorganic micronutrients

2. Verify the impact of integrated nutrient management on soil health.

\section{Effect of integrated nutrient management on yield and yield characteristics of rice}

Yadav et al., (2015) further reported that rice yield was generally scandalous as $25 \%$ nitrogen was replaced with green leaf faces $+100 \%$ NPK fertilizer in the structure of the rice grain, which changed the structure.

Mehedi et al., (2019) A more visible number of tumblers, stuffed ears, a weight of 1000 grains and an ideal rice yield were obtained using 120:60: $45 \mathrm{~kg} \mathrm{~N}: \mathrm{P}_{2} \mathrm{O}_{5}: \mathrm{K}_{2} \mathrm{O}_{\text {ha }}{ }^{-1}$ mixed with farm excrement as special sources of NPK and control.

Virdia and Mehta (2018) found that the use of $20 \mathrm{t} /$ ha of pressed sludge in the vicinity of the proposed fertilizer gave the highest grain yield, corresponding to a reduction in the size of the sludge of $15 \mathrm{t} / \mathrm{ha}+\mathrm{RDF}$ in the years 2000 and 2005 and with or FYM @ 10, equivalent to / ha + CDR in 1995. This may be the result of advances in the provision of more supplements of organic matter, which in addition to creating regular physical properties of the soil, which are food central to microorganisms. Liquid natural fertilizers contain a limited amount of supplements. Applied to income, it erases disproportionately similar attributes in a physical, compound, and physiological terms and coordinates the key part that rekindles collaboration for progress. The height of the plant is much more developed $(27.2 \mathrm{~cm})$, the number of leaves (33.3) and the yield per plant $(38.5 \mathrm{~g})$ if they deviate from the mine debris + RDF. The use of $3 \%$ Panchagavya significantly increased the grain yield ( $17.7 \mathrm{q} / \mathrm{ha}$ ), the number of 12 seeds per box and the weight of 100 seeds $(4.0 \mathrm{~g})$ when the part proposal 
of the diverted fertilizer. The result showed that ingress/slope ratios, ear length, ear fill, seed density, grain yield, and straw yield in the sprayed Panchgavya treatment were estimated to be $3 \%$ higher overall.

The use of $33 \mathrm{t}$ FYM $8 \mathrm{t} /$ ha of neem expeller significantly increases the grain yield (20.5 q/ ha) and the straw yield (24.5 q / ha) of soybeans. While the highest crude protein $(19.3 \%)$ was found in the treatment, target dependent CRTS supplements received $25 \mathrm{q} / \mathrm{ha}$ (50145: $43 \mathrm{NPK} \mathrm{kg/ha)} \mathrm{saw}$ the use of vermicompost @ $2.5 \mathrm{t} / \mathrm{ha}$, the seed close to the treatment of Azospirillum and PSB they worked to transform the events and the nature of sorghum and provided the highest seed yield (21.7 q / ha). The use of FYM @6 t / ha + Rhizobium + PSM essentially expanded plant growth habit $(32.9 \mathrm{~cm})$, unit weight per plant (11.9), seed list (55.3 g) and yield (1278 kg/ha). Sharma (2013), found that rice yield, improvement and yield credits were considered best when half of the $\mathrm{N}$ was used in manure and half in NPK in rice handling facilities. In addition to the generally higher yield of rice and straw grains $\left(5.52 \mathrm{t} \mathrm{ha}^{-1}\right.$ and $6.73 \mathrm{t} \mathrm{ha}^{-1}$ independently of each other), $70 \%$ of the recommended proportion of artificial fertilizer and 3 tons of poultry compost corral was $70 \%$ NPKS alone and control. The use of fertilizer NPK: GV: Zn (application to the soil) in quantities of 120-90-60 kg ha-1: $10 \mathrm{t} \mathrm{ha}^{-1}: 10 \mathrm{~kg} \mathrm{ha}^{-1}$ essentially provides the height of the plant, the number of revolutions, the number of ears, the number of spikelet's, the weight of 1000 grains, the yield and the straw yield of the paddy rice when it was only from NPK, and the control found that the yield was generally that of the grains and the Rice straw with the most outrageous use was the recommended ratio of $50 \%$ nitrogen to urea $+50 \%$ nitrogen proposed by vermicompost. In addition, it was observed that the yield of rice straw was 3.7, 15.9 and $20.7 \%$ higher when NPK was applied with agricultural manure, vermicompost and poultry manure, regardless of whether it was different only from NPK, it was also found that more wood turners $(28 \%)$, more ear $/ \mathrm{m}^{2}(60 \%)$, number of filled seeds $/ \mathrm{m}^{2}$ $(20.6 \%)$, Spikelets per ear (19.6\%) and more grain $(30.6 \%)$ with use solidified from natural compost and differentiated compounds and fertilizer produced alone (IARI. Annual Report 2005-2006).

Mahmud et al., (2016), showed that the use of an average amount of excrement of the substance with $4 \mathrm{tha}^{-1}$ of manure provided the most scandalous performance. More than one part of NPKS manure from industrial sources has been found to reduce rice yield. The results also showed the size of the largest plant, the effective slope of flipper 1 , the length of the pennant leaves, the length of the ear, the full kernels of ear ${ }^{-1}$, the weight of 1000 kernels, the El grain yield, straw yield and normal yield was from the mixture of $4 \mathrm{t} \mathrm{ha}^{-1}$ of antiparasitic fertilizer with $100 \mathrm{~kg} / \mathrm{ha} \mathrm{N}, 16 \mathrm{kgha}$
${ }^{1} \mathrm{P}, 66 \mathrm{kgha}^{-1} \mathrm{~K}, 12 \mathrm{kgha}^{-1} \mathrm{~S}$. The Rice can be generously expanded with mixed stools if a natural fertilizer is used sensibly found that the DRR Dhan 39 group provided the highest quantifiable wheat and straw yield with half the natural vermicompost fertilizer, 5\% Jeevamrutha and 3\% Panchagavya and half the inorganic NPK fertilizer. Similarly, $100 \%$ RDF + poultry manure $\left(3\right.$ tha $\left.^{-1}\right)+$ $3 \%$ Panchakavya leaf rainfall was shared during the rain, at the beginning of the ear and half before germination as part of the enrichment plan. Integration executives have seen the practice for better return and complementary support.

Kumar et al., (2014), found that the use of natural and inorganic dietary supplements in the mixture lengthened the performance points. The number of ears $/ \mathrm{m}^{2}$, length of ear, ear and specific gravity followed by a $100 \% \mathrm{EBS}+5 \mathrm{t} / \mathrm{h}$ treatment with parasite excrement. In addition, several drugs were more effective than the control. The immediate conclusion was similar. Relying on natural fertilizers, which could serve as a lazy transport source of $\mathrm{N}$, to coordinate even better with $\mathrm{N}$ and the provision of various nutritional supplements with the stress of the rice harvest, this could reduce the difficulty of $\mathrm{N}$ and add capacity to promote the use of food supplements, especially the mixture of organic fertilizers nitrogen, nitrogen and phosphorus (500: 120: 90 $\mathrm{kg} \mathrm{ha}^{-1}$ ) overcomes all excess drugs including only $\mathrm{P}$ and $\mathrm{N}$, in turn, $\mathrm{m}^{-2}$, number of ears $\mathrm{m}^{-2}$, number of spikelet ears ${ }^{-1}$, percentage of common pieces, the weight of 1000 grains $(\mathrm{g})$ and rice yield $\left(\mathrm{t} \mathrm{ha}^{-1}\right)$.

Baishya et al., (2015), among the supplements practiced by the municipality, the harvest with $2.5 \mathrm{t}$ of manure $\mathrm{ha}^{-1}+$ $125 \% \mathrm{CDF}\left(75+16.5+31.3 \mathrm{~kg} \mathrm{NP}\right.$ and $\left.\mathrm{K} \mathrm{ha}^{-1}\right)$ registered the largest plants, the strongest, ear length, grain, and straw yield. followed by $2.5 \mathrm{t}$ of poultry waste $\mathrm{ha}^{-1}+100 \% \mathrm{CDF}$ $\left(60+13.1+25 \mathrm{~kg} \mathrm{~N}, \mathrm{P}\right.$ and $\mathrm{K} \mathrm{ha}^{-1}$ and $5 \mathrm{t} \mathrm{FYM} \mathrm{ha}{ }^{-1}$ almost $125 \% \mathrm{CDF}\left(75+16,5+31.3 \mathrm{~kg} \mathrm{~N}, \mathrm{P}\right.$ and $\mathrm{K} \mathrm{ha}^{-1} \mathrm{In}$ any case, among natural sources, the expansion of parasitic manure $\left(1 \mathrm{tha}^{-1}\right)$ resulted in a better rebound in events and grain yield, followed by $2.5 \mathrm{t}$ of Poultry manure $\mathrm{ha}^{-1}$ and $5 \mathrm{t}$ FYM ha ${ }^{-1}$. A direct result of the improved and optimal availability of compost-producing supplements for pests when diverted from various natural fertilizer sources. This is consistent with the usage disclosures recommended nitrogen $100 \%$ urea in the first year of test and the second test, the annual use of 50\% suggested a part of nitrogen from the vermicompost and the rest of the compound excrement (urea) determined.

Moe et al., (2019), reported that more gymnasts were found with the CF50PM50 treatment at all stages of progression. The most scandalous number of spinners was observed at 40 DAT; 34.73 and 38.22 curves per slope in the CF50PM50 charts in 2017 and 2018 independently. 


\section{Impact of integrated nutrient management (INM) on soil health}

\section{Why Integrated Soil Fertility Management?}

To maintain soil fertility and increase productivity using only natural resources, a large proportion of natural compost would be needed to keep up with the abundance of soil in each field. In any case, the opposite approach, simply using inorganic fertilizers, can lead to high crop yields in a short time. In any case, this has an impact on the structure of the soil, which leads to the decomposition of natural matter and the regular alteration of atmospheric agents. Therefore, the best way for soil fertility is to mix inorganic and natural excrement to increase soil efficiency and soil maturity by more reasonable means and to reduce the damage caused by natural compost (100\% NPK + FYM) created additional soil conditions. As NPK fertilizer treatment shows, soil ages while natural compost + NPK regulations increase soil $\mathrm{pH}$.

Tharmarajet al., (2011), reported that the use of vermicompost increased the physical properties (water retention threshold, porosity, and stagnation), the properties of the substance ( $\mathrm{pH}$ and EC), as well as the fertility of the crop, increases usually. $\mathrm{N}, \mathrm{P}, \mathrm{K}, \mathrm{Ca}$ and $\mathrm{Mg}$ on control and application alone, the effect of a coordinated supplement on soil fertility Soil maturity advice was weighted and the results showed that the highest state and micronutrients in the soil In the treatment, half of RDN $+50 \% \mathrm{~N}$ to FYM + $\mathrm{BF}+$ Panchagavya @ 3\% rain of leaves, similar results were obtained $\mathrm{N}, \mathrm{P}, \mathrm{K}, \mathrm{Ca}, \mathrm{Mg}, \mathrm{Fe}, \mathrm{Mn}, \mathrm{Zn}$ and $\mathrm{Cu}$ were found in the artificial stool treatment, followed by vermicompost + vermicompost medications.

Dubey et al., (2019), reported that an enrichment of the natural substance carbon and nitrogen was observed in the same way as the use of the substance phosphorus and potassium in relation to its initial state in a $100 \%$ natural complete picture with all the management of facilities until the zenith of the fourth cycle of action. Natural carbon and nitrogen levels were kept up to date in all respects and phosphorus and potassium showed a slight decrease from the initial value with the $100 \%$ inorganic supplement.

Baishya et al., (2015), opined that the yield of $2.5 \mathrm{t}$ of bird manure ha ${ }^{-1}$ close to $75 \mathrm{~kg} \mathrm{~N}+16.5 \mathrm{~kg} \mathrm{P}+31.3 \mathrm{~kg} \mathrm{~K} \mathrm{ha}^{-1} \mathrm{a}$ colossal improvement in natural carbon, nitrogen, phosphorous and potassium levels of the soil showed a state to be harvested later than the harvest. that the use of $90 \mathrm{~kg}$ of nitrogen as half rice straw manure + half nitrogen as poultry manure has meant that over the years more substances N, P and K were made available from the soil of other treatment mixtures. The soil organic carbon (SOC) at the soil surface $(0-15 \mathrm{~cm})$ has not expanded in general or sufficiently by 15 years of drug fertilization $(\mathrm{N})$ but has expanded significantly by the revision of compost and straw
[FYM and FYM (Farmyard Manure) + GM (Green Manure/SPM (sulphitation press-mud)]. Therefore, it is important to track the yield trend down to the soil or add manure to the soil surface to further promote the SOC level. The immense runoff of straw or manure, despite repairs with inorganic fertilizers, will help limit carbon sequestration and improve food security in the region.

Mallikarjun and Maity (2018), reported that the highest number of bacteria (39.4 x $105 \mathrm{CFU} \mathrm{g}^{-1}$ and $40.5 \times 105 \mathrm{CFU}$ $\mathrm{g}^{-1}$, infectious people (14.06 x $103 \mathrm{CFU} \mathrm{g}^{-1}$ and $15,08 \times 103$

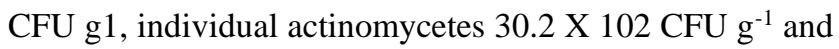

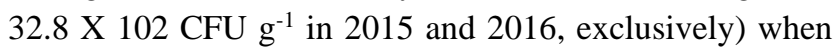
half $\mathrm{N}$ is used as compound fertilizer with $25 \%$ FYM close A doubling of the age of Azollain, were quantifiable in the standard when using From the control, $75 \%$ of $\mathrm{N}$ was highlighted as the excrement of the substance in the natural sources of Azolla nitrogen.

A function of supplements (INM) or a function of Supplements Stocks (Indigenous Nitrogen Supply) contribute to the efficient use of excrement that has been developed in coordination with natural food supplements, mineral and natural food supplements. This method is based on maintaining the subsistence level of plants in order to achieve a certain level of creating yield by examining the usefulness of all normal plant food sources in an unchanged manner, taking into account each pattern of change and the evolution of circumstances. The safety of natural fertilizers coordinates the intake of supplements, greatly affects the formation, creates more soil quality (physical, compound, and regular) and transfers result synergistic of the plants. INM consolidates regular and ongoing demonstrations of frame completion into an ideal sound biologically profitable development facility that pays for uses of every conceivable natural food source (mineral and normal) in a prudent, practical, and collaborative manner. It facilitates the correspondence between the sources of the input and the results intended exclusively to classify the restorative interest of the performance and its delivery in its ecological components.

The coordinated use of natural and inorganic manure over a long period reduced soil reactions by $0.22 \%$ compared to the use of inorganic fertilizers alone. $\mathrm{N}$ and Pare the same or more evident with respect to the integration of the basic soil levels, and then impressively the richness of the soil expands under the incessant consolidation of rice straw with green manure in the vicinity of inorganic compost Average $\mathrm{P}$ (Phosphorus) remaining $12.7 \%$ and average $\mathrm{K}$ (Potassium) of $14.3 \%$ when deviating from drugs that simply use inorganic food supplements (Kharub et al., 2003). Sesbania green manure on rice, incorporated with inorganic fertilizer, increased available $\mathrm{N}$ from 5.8 to 22.0 
$\mathrm{kg} \mathrm{ha}^{-1}$, on average. $\mathrm{P}$ from 1.4 to $3.8 \mathrm{~kg} \mathrm{ha}^{-1}$ and average $\mathrm{K}$ from 2.2 to $17.9 \mathrm{~kg} \mathrm{ha}^{-1}$.

Liu et al., (2014), in growing soils below $40 \mathrm{t} \mathrm{ha}^{-1}$ biochar, the water-stable soil aggregate $(>0.25 \mathrm{~mm})$ in the soil layer from 0 to $15 \mathrm{~cm}$ had a surprising complement for various drugs, particularly scale, all with an atomic size greater than $>2 \mathrm{~mm}$, suggesting that the biochar in the soil is combining to create more soil structure have shown that natural adjustments with high levels of bioavailable $\mathrm{C}$ from cellulose can promote infectious growth and further promote soil structure by modifying soil aggregates, requiring the use of natural enhancements to control the soil microbial environment and accumulation in the soil promotes soils. The use of natural adaptations such as compost is a reasonable mechanical assembly to recover the natural supply of carbon from the soil. The substance used a multidisciplinary approach to investigate the regular properties of soils, which are made up of several provincial properties. They observed a scandalous reduction in soil microbial biomass, parasitic mycelium, and all enzyme activities in soils with minimal natural substance $\mathrm{C}$ and increased horticulture without the use of natural changes.

The use of compost can have an impact on the microbial composition of the soil, defined by an undeniably valuable result on the amount of small organic spore-forming units with an additive directly linked to the manure part. Also concentrated in the soil, with high salinity, the use of compost can opt for an improvement of natural fertility $(0$, 50, 100 and $150 \mathrm{t} \mathrm{ha}^{-1}$ ) in salty soil(Ouni et al., 2013). They saw the addition of natural soil material and therefore an improvement in microbial biomass and some practices related to the substances. In each case, the results were compared in the presence of the best piece of compost $(150$ $\left.\mathrm{t} \mathrm{ha}^{-1}\right)$, selecting specific decrease inactivity. This could be attributed to the normal dangerous effects of the minor ingredients in this compost (Garcia-Gil et al., 2000).

Wang et al., (2014), showed that the extractable K, Ca, Na, and $\mathrm{Mg}$ ratios generally increased 60 to $670 \%$ later with the expansion of biochar. Soil substance K ranged, for example, between 42 and $324 \mathrm{mg} \mathrm{kg}^{-1}$.

\section{Influence of the INM on the quality of the rice grain}

Ebaidand El-Hissewy (2000), showed that an increase in nitrogen excretion from 0 to $165 \mathrm{~kg} \mathrm{~N} \mathrm{ha}^{-1}$ generally increases the peeling rate of the rice variety Sakha 101. The main benefits of the peeling rate were $165 \mathrm{~kg} \mathrm{~N}^{-}$ ${ }^{1}$ observed, followed by $110 \mathrm{~kg} \mathrm{~N} \mathrm{ha}^{-1}$. This development was due to the use of a nitrogen-expanded grain fill rate, which reduced the thickness of the body.
Sravan and Singh (2019), reported that the protein content of cereals and the yield of basmati rice differed due to the changed degrees of maturation and that the bio-vaccines had a higher protein content, considering the higher $\mathrm{N}$ content in the Beans. Almost identical differentiation was also found in the protein content of the varieties. Higher protein levels and yields when using bio vaccines could be the result of a predictable nitrogen supply and its efficient growth in cereals; The more visible nitrogen content in the grain changed the content of the grain components Integrated supplement frames recorded the most outrageous properties for quality attributes, the use of whole supplements as an inorganic source showed handling of $4.2 \%$ in less than the use of organic products in the mix. FYM provided tremendous reach and reduced dietary supplements to ideal amounts, resulting in high-quality work. Quality limits have improved thanks to the increased use of natural and inorganic food supplements, long-term nitrogen. Differences in the peeling, handling, and recovery of leaded rice with organic inoculants have also been reported.

Soils have become inadequate not just insignificant plant supplements like nitrogen, phosphorus and sometimes, potash yet additionally in secondary supplements, like sulfur, calcium, and magnesium. Micronutrients like zinc, boron and partially iron, manganese, copper, and molybdenum have likewise been accounted for to be lacking. Insufficiency of micronutrients during the most recent thirty years has grown in both, size, and degree due to expanded utilization of high examination fertilizers, utilization of high yielding crop assortments and expansion in cropping force. This has turned into a significant requirement for the creation and usefulness of a few crops.

It is additionally expected to help and promote utilization of gypsum and lime or dolomite as wellsprings of sulfur and calcium, individually, in regions planted to Kharif and rabi beats in chosen States, as lack of calcium in corrosive soils and that of sulfur in beat developing regions has been expanding because of kept mining by crops and utilization of without fertilizers.

Accessibility of plant supplements to crops has a solid bearing on the physico-substance nature of soils.

\section{Plant Micronutrients:}

Out of 17 supplements set up as fundamental for plant development, 6 are needed in little amounts and hence called micronutrients. They are zinc, boron, iron, manganese, molybdenum, and copper. Overall principles for guaranteeing ideal crop reaction to micronutrient application are described underneath.

Table 4: Essential nutrients for plant growth. 


\begin{tabular}{|c|c|c|c|}
\hline $\begin{array}{l}\text { Primary or } \\
\text { macronutrients }\end{array}$ & $\begin{array}{l}\text { Secondary or } \\
\text { macronutrients }\end{array}$ & Micronutrients & $\begin{array}{l}\text { Non-mineral elements } \\
\text { (from air and water) }\end{array}$ \\
\hline $\begin{array}{l}\text { Nitrogen, } \\
\text { Phosphorus, } \\
\text { Potassium. }\end{array}$ & $\begin{array}{l}\text { Calcium, } \\
\text { Magnesium, } \\
\text { Sulfur. }\end{array}$ & $\begin{array}{l}\text { Boron, Chlorine, Copper, Iron, } \\
\text { Manganese, Molybdenum, } \\
\text { Zinc, Nickel, Cobalt. }\end{array}$ & Oxygen, Carbon, Hydrogen. \\
\hline
\end{tabular}

\section{Major elements}

\section{Nitrogen (N)}

Nitrogen is a vital component in plant development. It is found in all plant cells, in plant proteins and hormones, and in chlorophyll.

Air nitrogen is a wellspring of soil nitrogen. For example, vegetables fix barometrical nitrogen in their roots; in any case, manure industrial facilities use nitrogen from the air to make ammonium sulfate, ammonium nitrate, and urea. When applied to soil, nitrogen is changed to a mineral structure, nitrate, so that plants can take it up.

Soils high in organic matter. For example, chocolate soils are, for the most part, higher in nitrogen than podzolic soils. Nitrate is effectively drained out of the soil by the weighty downpour, bringing about soil fermentation.

\section{Phosphorus (P)}

Phosphorus helps move energy from daylight to plants, animates early root and plant development, and rushes development.

Not very many Australian soils have sufficient phosphorus for supported crop and field creation and the North Coast is no special case. The most widely recognized phosphorus source on the North Coast is superphosphate, produced using rock phosphate and sulfuric corrosive. All manures contain phosphorus; manure from grain-took care of creatures is an especially rich source.

\section{Potassium (K)}

Potassium expands the energy and sickness resistance of plants, helps structure, and move starches, sugars, and oils in plants, and can further develop natural product quality.

Potassium is low or inadequate on a significant number of the sandier soils of the North Coast. Likewise, weighty potassium evacuation can happen on soils utilized for concentrated brushing and serious green crops (like bananas and custard apples).

Muriate of potash and sulfate of potash are the most widely recognized wellsprings of potassium.

\section{Calcium (Ca)}

Calcium is fundamental for root wellbeing, the development of new roots and root hairs, and the advancement of leaves. It is for the most part hard to come by in the North Coast's corrosive soils. Lime, gypsum, dolomite, and superphosphate (a combination of calcium phosphate and calcium sulfate) all stock calcium. Lime is the least expensive and most appropriate choice for the North Coast; dolomite is valuable for magnesium and calcium insufficiencies, yet whenever utilized over a significant stretch will unbalance the calcium/magnesium proportion. Superphosphate is valuable where calcium and phosphorus are required.

\section{Magnesium (Mg)}

Magnesium is a critical part of chlorophyll, the green shading material of plants, and is crucial for photosynthesis (the change of the sun's energy to nourishment for the plant). Lacks happen mostly on sandy corrosive soils in high precipitation regions, particularly whenever utilized for escalated agriculture or dairying. Weighty applications of potassium in fertilizers can likewise deliver magnesium inadequacy, so banana cultivators need to watch magnesium levels since bananas are enormous potassium users.

Magnesium inadequacy can be overwhelmed with dolomite (a blended magnesium-calcium carbonate), magnesite (magnesium oxide) or Epsom salts (magnesium sulfate).

\section{Table 5: Trace elements.}

\begin{tabular}{|l|l|}
\hline Iron (Fe) & $\begin{array}{l}\text { Iron is a constituent of many mixtures that manage and advance the development and is promptly } \\
\text { accessible in the North Coast's corrosive soils. }\end{array}$ \\
\hline $\begin{array}{l}\text { Manganese } \\
(\mathbf{M n})\end{array}$ & $\begin{array}{l}\text { Manganese assists with photosynthesis. It is openly accessible in the North Coast's corrosive soils, } \\
\text { regularly in harmful sums in exceptionally corrosive soils, however, can be inadequate in sandy soils. } \\
\text { Poisonousness is helped with lime. }\end{array}$ \\
\hline Copper $(\mathbf{C u})$ & $\begin{array}{l}\text { Copper is a fundamental constituent of proteins in plants and is promptly accessible in North Coast soils, } \\
\text { despite the fact that it very well may be insufficient in red soils. Abuse of one more minor component, }\end{array}$ \\
\hline
\end{tabular}




\begin{tabular}{|c|c|}
\hline & $\begin{array}{l}\text { molybdenum, can cause copper inadequacy in creatures. Poisonousness can be an issue for horticulturists } \\
\text { who consistently use Bordeaux combination or copper oxychloride splashes to control diseases on } \\
\text { horticultural crops. }\end{array}$ \\
\hline Zinc (Zn) & $\begin{array}{l}\text { Zinc helps in the creation of a plant chemical liable for stem prolongation and leaf extension. It is promptly } \\
\text { accessible in corrosive soils yet consolidates effectively with iron in the North Coast's red soils. This is } \\
\text { handily relieved with the expansion of zinc sulfate or squashed zinc minerals. Organic product trees can } \\
\text { be showered with zinc. }\end{array}$ \\
\hline Boron (B) & $\begin{array}{l}\text { Boron assists with the development of cell dividers in quickly developing tissue. Lack lessens the take- } \\
\text { up of calcium and hinders the plant's capacity to utilize it. It is constantly inadequate in North Coast soils } \\
\text { utilized for cultivation however this is effortlessly cured with borax applied to the dirt. }\end{array}$ \\
\hline $\begin{array}{l}\text { Molybdenum } \\
\text { (Mo) }\end{array}$ & $\begin{array}{l}\text { Molybdenum (Mo) Most South Carolina soils contain from } 1 \text { to } 6 \text { pounds of molybdenum for each section } \\
\text { of land; above and beyond to meet most crop prerequisites. Accordingly, South Carolina soils are not } \\
\text { tried for molybdenum accessibility. In any case, molybdenum is suggested for vegetables developing on } \\
\text { corrosive soils when an inadequacy is suspected. Molybdenum isn't suggested for application on non- } \\
\text { vegetable crops. } \\
\text { Soil pH is the significant soil factor influencing molybdenum plant accessibility. By and large, assuming } \\
\text { that the dirt pH is more prominent than } 6.0 \text {, an insufficiency isn't probably going to happen. Assuming } \\
\text { the dirt pH is beneath } 6.0 \text { and molybdenum inadequacy is suspected, the suggested application rate for } \\
\text { most vegetable crops is } 2 \text { to } 8 \text { ounces molybdenum for each section of land applied as either a seed } \\
\text { treatment or foliar shower. } \\
\text { Molybdenum helps microbes and soil organic entities convert nitrogen in the air to dissolvable nitrogen } \\
\text { compounds in the dirt, so is especially required by vegetables. It is likewise fundamental in the } \\
\text { arrangement of proteins from dissolvable nitrogen compounds. } \\
\text { Molybdenum insufficiency is common in the North Coast's corrosive soils yet can be helped effectively } \\
\text { with applications of Mo super, molybdenum trioxide (applied during vaccination and lime pelleting of } \\
\text { vegetable seed), or sodium molybdate. Molybdenum exists in the soil solution as the molybdate (MnO }{ }_{4}^{2-} \\
\text { anion. }\end{array}$ \\
\hline
\end{tabular}

Source: Cammack R (1995), Dixo et al. 1995, Bertrand and Wolf 1967, Brady 2002.

\section{Sulfur (S)}

Sulfur is a constituent of amino acids in plant proteins and is associated with energy-creating processes in plants. It is liable for some flavour and scent compounds in plants like the fragrance of onions and cabbage.
Sulfur insufficiency isn't an issue in soils high in organic matter, yet it filters without any problem. On the North Coast Seas pray is a significant wellspring of environmental sulfur. Superphosphate, gypsum, essential sulfur, and sulfate of alkali are the principal manure sources.

Table 6: List of Molybdenum-containing Commercial Fertilizers:

\begin{tabular}{|l|l|l|l|}
\hline Source & Formula & Water Solubility & \% Mo \\
\hline Ammonium molybdate & $\left(\mathrm{NH}_{4}\right)_{6} \mathrm{Mo}_{7} \mathrm{O}_{24}$ & Soluble & 53 \\
\hline Molybdenum trioxide & $\mathrm{MoO}_{3}$ & Soluble & 66 \\
\hline Molybdenum dioxide & $\mathrm{MoO}_{2}$ & Soluble & 75 \\
\hline Sodium molybdate & $\mathrm{Na}_{2} \mathrm{MoO}_{4} 2 \mathrm{H}_{2} \mathrm{O}$ & Soluble & 39 \\
\hline
\end{tabular}

\section{Macronutrients and Micronutrients}

The fundamental elements can be partitioned into two gatherings: macronutrients and micronutrients. Supplements those plants need in bigger sums are called macronutrients. About portion of the fundamental elements is considered macronutrients: carbon, hydrogen, oxygen, nitrogen, phosphorus, potassium, calcium, magnesium, and sulfur. The first of these macronutrients, carbon (C), is needed to frame carbs, proteins, nucleic acids, and 
numerous different mixtures; it is accordingly present in all macromolecules. By and large, the dry weight (barring water) of a phone is $50 \%$ carbon.

\section{Forms of essential plant nutrients}

To be utilized by a plant, a fundamental supplement should be separated into its essential structure. The supplement should be either a decidedly charged particle (cation) or an adversely charged particle (anion). A plant can't utilize organic mixtures, like those in manure or dead leaves, until they are separated into their natural or ionic structures.

Likewise, plants can't utilize a component that isn't in the legitimate structure (a particular particle) regardless of whether it is available in high focuses in the dirt. For instance, the presence of iron $(\mathrm{Fe})$ in the dirt won't ensure that enough of the appropriate iron particles, $\mathrm{Fe}^{2+}$ or $\mathrm{Fe}^{3+}$, will be accessible to the plant.

\section{Commercially available nutrients}

\section{Ammonia}

Ammonia - This item is the beginning stage for most of the $\mathrm{N}$ manure industry. It very well may be utilized straightforwardly or changed over into an assortment of normal fertilizers. Exceptional wellbeing and the board rehearse are required.

\section{Ammonium Nitrate}

Ammonium Nitrate - Ammonium nitrate was the principal strong nitrogen $(\mathrm{N})$ fertilizer created for an enormous scope, yet its notoriety has declined as of late. It has been a generally expected $\mathrm{N}$ source since it contains both nitrate and ammonium and it has a somewhat high supplement content.

\section{Calcium Carbonate (Limestone)}

Calcium Carbonate (Limestone) - Calcium carbonate, the main part of limestone, is a broadly utilized correction to kill soil corrosiveness and to supply calcium (Ca) for plant nourishment. The expression "lime" can allude to a few items, yet for farming use it for the most part alludes to ground limestone.

\section{Calcium Nitrate}

Calcium nitrate is a profoundly soluble wellspring of two plant supplements. Its high solubility makes it famous for providing a quickly accessible wellspring of nitrate and calcium straightforwardly to the soil, through irrigation water, or with foliar applications.

\section{Diammonium Phosphate}

Diammonium Phosphate - Diammonium phosphate (DAP) is the world's most generally utilized phosphorus (P) fertilizer. It is produced using two normal constituents in the fertilizer business and it is famous due to its somewhat high supplement content and its fantastic physical properties.

\section{Gypsum}

Gypsum - Gypsum is a typical mineral acquired from the surface and underground stores. It tends to be an important wellspring of both calcium $(\mathrm{Ca})$ and sulfur $(\mathrm{S})$ for plants and may give advantages to soil properties in explicit conditions.

\section{Potassium Chloride}

Potassium Chloride - Potassium fertilizers are normally used to beat plant inadequacies. Where soils can't supply how much $\mathrm{K}$ is needed by crops, it is important to enhance this fundamental plant supplement. Potash is an overall term used to portray an assortment of K-containing fertilizers utilized in agriculture. Potassium chloride $(\mathrm{KCl})$, the most usually utilized source, is likewise much of the time alluded to as muriate of potash or MOP (muriate is the old name for any chloride-containing salt). Potassium is dependably present in minerals as a solitary charged cation $\left(\mathrm{K}^{+}\right)$.

\section{Potassium Magnesium Sulfate (Langbeinite)}

Potassium Magnesium Sulfate (Langbeinite) - Langbeinite is an extraordinary wellspring of plant sustenance since three fundamental supplements are normally consolidated into one mineral. It gives a promptly accessible stock of $\mathrm{K}$, $\mathrm{Mg}$, and $\mathrm{S}$ to developing plants.

Source: (https://www.ipni.net/specifics-en).

\section{Synthetic mixtures of micronutrients are of two kinds:}

1. Chelates synthetic mixtures as a heterocyclic ring having a metal particle appended by coordinate bonds to something like two non-metal particles, for example, EDTA, DTPA HEDTA, EDDHA, NTA, normal chelated micronutrients being Zn-EDTA and Fe-EDTA.

2. Inorganic salts, for example, zinc sulfate $\left(\mathrm{ZnSO}_{4}\right)$, copper sulfate $\left(\mathrm{CuSO}_{4}\right)$, ferrous sulfate $\left(\mathrm{FeSO}_{4}\right)$, manganese sulfate $\left(\mathrm{MnSO}_{4}\right)$, and so forth, are normally utilized as micronutrient fertilizers.

Every one of these is soluble in water and can be utilized as a soil application or foliar shower Boron (B), Copper $(\mathrm{Cu})$, Chlorine ( $\mathrm{Cl})$, Iron $(\mathrm{Fe})$, Zinc $(\mathrm{Zn})$, Manganese (Mn), Molybdenum (Mo).

Plant supplements incorporate gases, metals, and nonmetals. All exist normally, in both inorganic and organic structures. Three of the supplements, nitrogen (N), phosphorus (P), and sulfur (S), are available in both inorganic and organic structures. Crops fill in an exceptionally flimsy layer of the Earth's covering, so nutrient levels should be kept up with by the expansion of both organic (plant and creature deposits) and inorganic (made mineral fertilizers) sources. Now and then the word 
organic is utilized regarding food. Regularly it is utilized to propose that organic food varieties contain just great or normal elements that in some way improve plant and creature wellbeing when contrasted with those food varieties grown with manufactured synthetic compounds. In reality, regardless of whether organic or inorganic, all elements are substances. The term organic connects with living (or the remaining parts of once-living) substances that contain carbon (C). Organic substances (dead plant or creature material in some phase of disintegration) are found in all agrarian soils and are continually experiencing significant change back to their inorganic structure. As they disintegrate, they add to the absolute soil inorganic supplement pool important to develop the world's food prerequisite. Endeavouring to isolate organic and inorganic supplements is troublesome and of restricted worth since nature's cycles are persistently cycling them starting with one structure then onto the next. All supplements go through normal cycles, following different pathways to their last objective of being assimilated and used by plants that develop all the nourishment for people and animals. All the while, a few, like $\mathrm{N}, \mathrm{P}$, and $\mathrm{S}$, cycle this way and that between the inorganic and organic pools.

Effect of organic nutrition on soil available nutrient status of $\mathrm{N}, \mathrm{P}, \mathrm{K}, \mathrm{S}, \mathrm{Mo}, \mathrm{Fe}, \mathrm{Zn}$
The use of organic manures fundamentally affected the accessible substance of $\mathrm{N}, \mathrm{P}, \mathrm{K}, \mathrm{S}, \mathrm{Mo}, \mathrm{Fe}$, and $\mathrm{Zn}$ in the soil at the collection of the crop (Table 7). The fundamentally most extreme substance of supplements $(\mathrm{N}$, $\mathrm{P}, \mathrm{K}, \mathrm{S}, \mathrm{Mo}, \mathrm{Fe}$, and $\mathrm{Zn}$ ) was seen under the treatment level P5 (poultry manure@ @ $\mathrm{tha}^{-1}$ ). The treatment V5 was likewise found measurably at standard with the treatment V5 (Vermicompost @ $5 \mathrm{t} \mathrm{ha}^{-1}$ ). The higher accessibility of mineral supplements in soil because of the use of manures (Vermicompost) could be attributed to the mineralization of manures, decrease in obsession and complexing properties of disintegration results of manures with micronutrients. More significant levels of mineral supplement in vermicompost treated plots could likewise be credited to the chelating activity of organic mixtures delivered during the deterioration of organic manures, which shield these cations from obsession, precipitation, oxidation, and draining of supplement at reap. The increment inaccessibility of supplements at collect of the crop may likewise be because of improved microbial movement and nitrogen obsession by the crop, cyclical change of insoluble micronutrients, upgraded versatility, or solubilization of local forms of supplements.

Table 7: Effect of organic and inorganic nutrition on the available status of $N, P, K$, and $S$ in soil at harvest of the crop.

\begin{tabular}{|c|c|c|c|c|}
\hline \multirow[t]{2}{*}{ Treatments } & \multicolumn{4}{|c|}{ Available content $\left(\mathrm{Kg} \mathrm{h} \mathrm{a}^{-1}\right)$} \\
\hline & $\mathrm{N}$ & $\mathrm{P}_{2} \mathrm{O}_{2}$ & $\mathrm{~K}_{2} \mathrm{O}$ & $\mathrm{S}$ \\
\hline \multicolumn{5}{|l|}{ Organic } \\
\hline$C_{0}($ Control $)$ & 135.01 & 15.45 & 152.60 & 7.78 \\
\hline$F_{10}\left(\mathrm{FYM} 10 \mathrm{th} a^{-1}\right)$ & 147.08 & 18.06 & 174.25 & 8.25 \\
\hline$V_{5}\left(\right.$ Vermicompost $\left.5 \mathrm{th} a^{-1}\right)$ & 158.4 & 20.10 & 190.25 & 8.65 \\
\hline$P_{5}\left(\right.$ Poultry manure $\left.5 \mathrm{t} \mathrm{h} a^{-1}\right)$ & 162.01 & 20.85 & 195.40 & 8.78 \\
\hline SEm \pm & 3.35 & 0.66 & 5.56 & 0.12 \\
\hline $\mathrm{CD}(\mathrm{P}=0.05)$ & 9.58 & 1.88 & 15.93 & 0.33 \\
\hline \multicolumn{5}{|l|}{ Inorganic nutrients } \\
\hline$M_{0}($ Control $)$ & 129.91 & 14.67 & 150.41 & 7.72 \\
\hline$M_{1}(\mathrm{~S})$ & 140.48 & 17.17 & 164.35 & 8.18 \\
\hline$M_{2}(\mathrm{~S}+\mathrm{Mo})$ & 152.43 & 19.33 & 185.24 & 8.28 \\
\hline$M_{3}(\mathrm{~S}+\mathrm{Mo}+\mathrm{fe})$ & 163.66 & 21.31 & 204.02 & 8.39 \\
\hline$M_{4}(\mathrm{~S}+\mathrm{Mo}+\mathrm{Fe}+\mathrm{Zn})$ & 166.64 & 21.11 & 209.11 & 8.51 \\
\hline SEm \pm & 3.74 & 0.73 & 6.22 & 0.13 \\
\hline $\mathrm{CD}(\mathrm{p}=0.05)$ & 10.80 & 2.12 & 17.96 & 0.37 \\
\hline
\end{tabular}


Effect of mineral nutrition on soil available nutrient status of $\mathrm{N}, \mathrm{P}, \mathrm{K}, \mathrm{S}$, Mo, Fe, Zn

The utilization of mineral supplements fundamentally expanded the accessible substance of soil at a gathering of the crop. The greatest substance of $\mathrm{N}, \mathrm{P}, \mathrm{K}$, and Fe were recorded under the treatment $\mathrm{M} 3$, though $\mathrm{S}$, Mo, and $\mathrm{Zn}$ were fundamentally recorded under the treatments M1, M2, M4 separately. The improvement in the status of soil might be credited to more biomass (leaves, roots, and dead cells of microorganisms) added by short during vegetables and expansion in advantageous nitrogen obsession, expansion in soil biomass, and microbial action. The increment in the accessible substance of the supplements may likewise be because of the direct expansion of these supplements in the fields of the exploratory crop. Synergism among nitrogen and iron, phosphorus and molybdenum positive communication among Mo and $\mathrm{Zn}$ may likewise be answerable for expansion in the accessible substance of these supplements.

Table 8: Effect of organic and inorganic nutrition on available status of $\mathrm{Fe}, \mathrm{Mo}, \mathrm{Zn}$, and OC of soil at harvest of the crop.

\begin{tabular}{|c|c|c|c|c|}
\hline \multirow{2}{*}{ Treatments } & \multicolumn{4}{|c|}{ Available content } \\
\hline & $\mathrm{Fe}\left(\mathrm{mg} \mathrm{kg}{ }^{-1}\right)$ & Mo $\left(\mathrm{mg} \mathrm{kg}^{-\mathbf{1}}\right)$ & $Z n\left(\mathrm{mg} \mathrm{kg}^{-\mathbf{1}}\right)$ & $\mathrm{OC}(\%)$ \\
\hline \multicolumn{5}{|l|}{ Organic } \\
\hline$C_{0}($ Control $)$ & 5.99 & 0.121 & 0.495 & 0.241 \\
\hline$F_{10}\left(\mathrm{FYM} 10 \mathrm{t} \mathrm{ha^{-1 }}\right)$ & 6.68 & 0.128 & 0.535 & 0.269 \\
\hline$V_{5}\left(\right.$ Vermicompost $\left.5 \mathrm{t} \mathrm{h} a^{-1}\right)$ & 7.28 & 0.138 & 0.570 & 0.277 \\
\hline$P_{5}\left(\right.$ Poultry manure $\left.5 \mathrm{th} a^{-1}\right)$ & 7.41 & 0.142 & 0.585 & 0.278 \\
\hline SEm \pm & 0.20 & 0.003 & 0.011 & 0.004 \\
\hline $\mathrm{CD}(\mathrm{P}=0.05)$ & 0.58 & 0.008 & 0.032 & 0.011 \\
\hline \multicolumn{5}{|l|}{ Inorganic nutrients } \\
\hline$M_{0}($ Control $)$ & 5.35 & 0.120 & 0.458 & 0.211 \\
\hline$M_{1}(\mathrm{~S})$ & 6.21 & 0.127 & 0.498 & 0.225 \\
\hline$M_{2}(\mathrm{~S}+\mathrm{Mo})$ & 7.02 & 0.142 & 0.547 & 0.240 \\
\hline$M_{3}(\mathrm{~S}+\mathrm{Mo}+\mathrm{fe})$ & 7.76 & 0.144 & 0.600 & 0.256 \\
\hline$M_{4}(\mathrm{~S}+\mathrm{Mo}+\mathrm{Fe}+\mathrm{Zn})$ & 7.85 & 0.148 & 0.669 & 0.273 \\
\hline SEm \pm & 0.23 & 0.003 & 0.012 & 0.004 \\
\hline $\mathrm{CD}(\mathrm{p}=0.05)$ & 0.66 & 0.009 & 0.036 & 0.013 \\
\hline
\end{tabular}




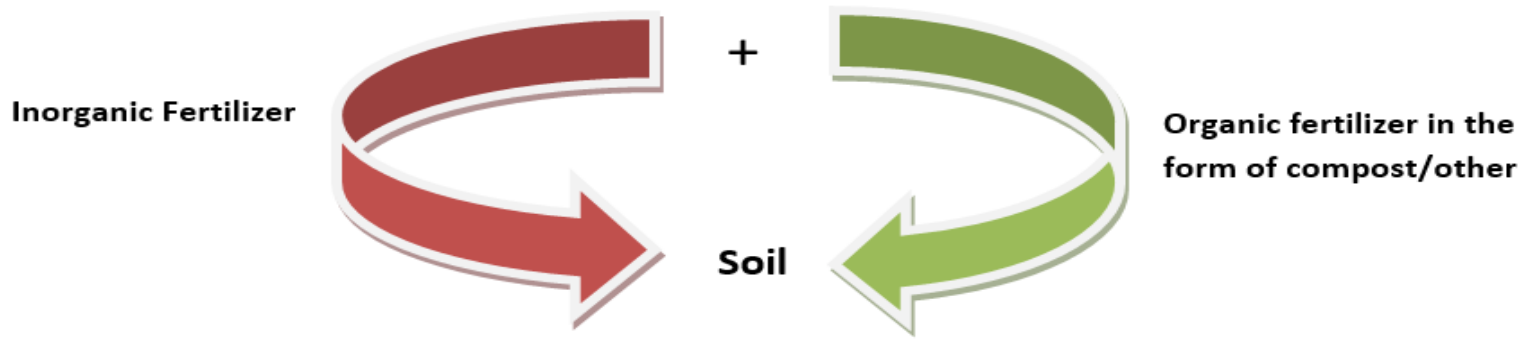

Best management system for increasing soil fertility

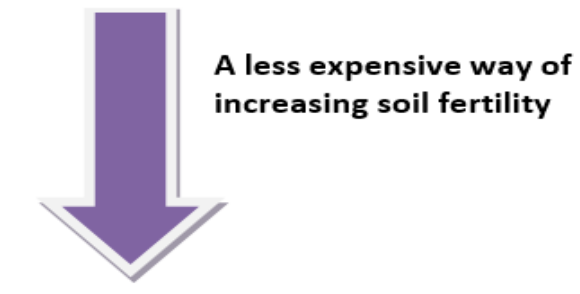

High Productivity

Fig. 1: Average nutrients for inputs and outputs and principles of integrated nutrient management systems

Source: Roba, T.B. (2018).

\section{CONCLUSION}

Overall, this audit work highlighted the work and importance of a coordinated addition to the framework structure, for example, natural and inorganic supplement sources as an administrative framework that can make the crop yield in the country reasonable. Natural fertilizers have more benefits after a long enough time, and they work differently than inorganic droppings. Natural fertilizer deals with the physical, regular, and material properties of soil, but supplements may not be readily available to plants. In any case, inorganic compost usually contains all the major ready-made plant supplements quickly and easily. Excessive use of inorganic manure in agribusiness can lead to soil degradation, soil maturation, and contamination. The richness of the soil incorporated into the planking system is an approach of choice for the sound and acceptable management of soil maturity and is illustrated by the reduction in the use of inorganic fertilizers and the combined use of inorganic excretions with natural materials. The possible results of the current audit series suggest that the development of $\mathrm{ZnSO}_{4}$ for corn is not only due to the higher DTPA-Zn content in the soil but has also kept it at a higher level. The solidification of $100 \%+$ NPK FYM in record time has increased the availability of micronutrients in the soil. In comparison to inorganic fertilisers, organic fertilisers provide higher long-term benefits. Organic fertiliser improves a soil's physical, biological, and chemical qualities, but nutrients may not be as easily available to plants.

Inorganic fertiliser, on the other hand, is usually available right away and contains all of the necessary nutrients.
Excessive use of inorganic fertilisers in agriculture can result in soil deterioration, acidification, and pollution of the environment. Organic fertilisers are a realistic option for soil fertility and productivity in the long run.

\section{REFERENCES}

[1] Sharma, (2012). Note on the content of secondary elements and microelements in fertilizers and fertilizers. Indian Journal of Agricultural Sciences, 45,80-85.

[2] Dixit and Gupta, (2015);Quyen and Sharma, (2013). AICRP main results on long-term fertilizer experiments, 197196.Soil Department, PAU, Ludhiana.

[3] Saha and others, (2017). AICRP Progress Report on SlowRelease Fertilizer Experience from 1997-98 to 19992000.Soil Department, Punjab Agrl. University, Ludhiana.

[4] Charyulu and Biswas, (2015).Long-term studies on the integrated use of organic and inorganic fertilizers in the corn-wheat-bovine cropping system in alluvial soils of Punjab. In: Proceedings of the national seminar on longterm management of soil fertility through integrated nutrient supply for plants, held 2-4 April 1998 at IISS, Bhopal.P.154168.

[5] Prasad, (2015).Influence of FYM on the content of organic carbon, $\mathrm{N}$ and $\mathrm{P}$ available in the soil during the different wheat growing seasons. Journal of the Indian Society of Soil Sciences,36, 269-273.

[6] Lodhiet al.,(2016).“Chemical Soil Analysis” (Prentice Hall of India. Pvt. Ltd., New Delhi).

[7] Virdia and Mehta (2018). Some aspects of the formation of zinc and copper phosphate in aqueous systems. Proceedings of the Soil Science Society of America 26,144-147.

[8] Yadav et al., (2015).Effect of continuous liming, fertilization, and cultivation on the extractable micronutrients DTPA in alfisol. Journal of the Indian Society of Soil Sciences, 41, 366-367. 
[9] Mehedi et al., (2019). Effect of the integrated use of organic fertilizers with chemical fertilizers in the rice cultivation system and its effects on soil health. Bangladesh J Agri Sci., 34:81-90.

[10] Sharma (2013). Summary of Agricultural Statistics, Department of Agriculture and Cooperation, Ministry of Agriculture, Government of India, New Delhi.

[11] Mahmud AJ, Shamsuddoha ATM, Haque MN. (2016).Effect of Organic and Inorganic Fertilizer on the Growth and Yield of Rice (Oryza sativa L). Nat Sci., 14(2):45-54.

[12] Kumar and others (2014). Biochar Modification Techniques for Rain Rice Production in Northern Laos, 1. Physical Properties of Soil, Leaf and Grain Yield SPAD.Res.,111:8184.

[13] Baishya et al., (2015) Productivity and quality of Basmati rice (Oryza sativa) in terms of nitrogen management.J Agron Indian, 61 (4): 467-473.

[14] Moe et al., (2019): Influence of organic and inorganic fertilizers on the yield and quality of corn silage with soy mix. Pair J.6: e5280.

[15] Tharmaraj K, Ganesh P, Kolanjinathan K, Suresh KR, Anandan A (2011). Influence of vermicompost and vermiwash on physicochemical properties of rice cultivated soil.Current Botany, 2011; 2(3):18-2.

[16] Dubey et al., (2019). Yield, profitability, and soil fertility thanks to sources of organic nitrogen (vermicompost) that replace chemical fertilizers in rice in the rainy season. Res., 36 (1): 4-7.

[17] Becker, M.; Ladha, J. K.; Ottow, J. C. G. (1994). Nitrogen Losses and Lowland Rice Yield as Affected by Residue Nitrogen Release. Soil Science Society of America Journal, 58(6), 1660-1665. doi:10.2136/sssaj1994.03615995005800060012x.

[18] Baishya, Lohit\& Rathore, S. \& Singh, D \& Sarkar, Dibyendu\& Deka, Bidyut. (2015). Effect of integrated nutrient management on rice productivity, profitability, and soil fertility. Annals of Plant and Soil Research. 17.

[19] Mallikarjun and Maity (2018). Long-term effects of NPK fertilizers and organic fertilizers on the stabilization index and carbon management in the rice and wheat cropping system. Res. Clarifying, 166: 59-66.

[20] Liu et al., (2014). Influence of integrated nutrient management practices on rice yield and nutrient uptake within the rice intensification system. Int $\mathbf{J}$ AdvAgri.Sci. Tech., 2 (1): 54-61.

[21] Wang Y, Yin R, Liu R (2014) Characterization of biochar from fast pyrolysis and its effect on chemical properties of the tea garden soil. J Anal Appl Pyrol., 110:375-381. doi:10.1016/j.jaap.2014.10.006.

[22] Ebaid and El-Hissewy, (2000).The volatile content of carbon affects plant growth and changes in soil nitrogen. Sol SciSoc Am J., 74: 1259-1270.

[23] Sravan and Singh (2019). Rice response to various sources of organic and inorganic nutrients in Parwanipur, Bara district, Nepal. J Agri Nat Res., 2 (1): 53-59.

[24] Ding, Y., Liu, Y., Liu, S., Li, Z., Tan, X., Huang, X., Zeng, C., Zhou, Lu, Zheng, B.,(2016). Biochar to improve soil fertility. A review. Agron. Support. Dev. 36: 36. doi. 10.1007 / s13593-016-0372-z.

[25] Dixit, KG and Gupta, BR (2000). Influence of agricultural manure, chemicals and organic fertilizers on the yield and quality of rice (Oryza sativa) and on soil properties. J Indian Soc. Soil Sci., 48: 773-780.

[26] Dubey, R., Sharma, RS and Dubey, DP (2014). Effects of organic, inorganic, and integrated nutrient management on plant productivity, water productivity and soil properties in various cultivation systems of rice in Madhya Pradesh, India. Intern J. Curr. Microbiol. App. Sci., 3 (2): 381-389.

[27] Gangmei, T.P. and George, P.J., (2017). Black Rice CV. "ChakhaoAmubi" (Oryza sativa L.) Response to Organic and Inorganic Sources of Nutrients on Growth, Yield and Grain Protein Content. Journal of Pharmacognosy and Phytochemistry, 6, 550-555.

[28] Gaud, VV 2004. Production potential and profitability of a rice cultivation system with integrated nutrient management. $\mathrm{PhD}$ thesis presented at Navsari Agricultural University, Navsari.

[29] Han, SH, Young, J., Hwang, J., Kima, SB and Parka, B. (2016). The effects of organic and chemical fertilizers on the growth and nutrient concentrations of yellow poplar (Liriodendron tulipiferaLin.) In a daycare system. Forest Science Technology, 12:137-143.

[30] Iqbal, A., He, L., Khan, A., Wei, S., Akhtar, K., Ali, I., Ullah, S., Munsif, F., Zhao, Q. and Jiang, L. 2019. Organic fertilizer combined with inorganic fertilizer: an approach to sustainable rice production by improving soil properties and nitrogen use efficiency. Agronomy 9, 651; doi: 10.3390 / agronomie9100651.

[31] Issaka RN, Buri MM, Nakamura S., and Tobita S. 2014. Comparison of different fertilizer management practices on rice growth and yield in the Ashanti region of Ghana. Agroforestry fishing. 3 (5): 374-379.

[32] Kumar, S. (2013). The role of biopesticides in sustainably feeding the nine billion global populations. J. Biofertil. Biopesticide. 4: e114. doi: 10.4172/2155-6202.1000e114.

[33] Mengel, K., Kirkby, E.A., Kosegarten, H., Appel, T.,(2001). Principles of Plant Nutrition. Kluwer Academic Publishers, Dordrecht, The Netherlands.

[34] Palaniappan S.P., Annadurai K., (2010). Organic farming: theory andpractices. Scientific Publishers, (India), Jodhpur, p 97.

[35] Jambhekar H., (1992). Use of earthworms as a potential source of decomposed organic wastes. In: Ghosh TK, Chakrabarti T, Tripathi G (eds) Biotechnology in environmental management, vol 1. A.P.H. Publishing Corporation, New Delhi, pp 135-145.

[36] Nagavallemma KP, Wani SP, Stephane Lacroix, Padmaja VV, Vineela C, BabuRao M, Sahrawat KL, (2004). Vermicomposting: Recycling wastes into valuable organic fertilizer. Global Theme on Agrecosystems Report no. 8. Patancheru-502324, Andhra Pradesh, India: International Crops Research Institute for the Semi-Arid Tropics $20 \mathrm{pp}$.

[37] Rupani PF, Ibrahim MH, Ismail SA, (2013). Vermicomposting biotechnology: recycling of palm oil mill 
wastes into valuable products. Intern J Recycl Org Waste Agricul., 2:10.

[38] Kanwar, A., \& Sharma, S. R., (2014). Effect of organic and inorganic nutrition on fertility status of soil and yield of vegetable cowpea. Annals of Arid Zone,53 (1), 17-20.

[39] Savoy H., (2009) Fertilizer and their use. Agricultural Extension Service. The University of Tennessee, pp 1-23.

[40] Srivastava, A. K., and Ethel Ngullie. "Integrated Nutrient Management: Theory and Practice." (2009).

[41] Cammack R., (1995). Splitting molecular hydrogen. Nature, 373:556-557.

[42] Dixo NE, Gazzola C, Blakeley RL, Zerner B (1995). Jack bean urease (EC 3.5.1.5). A metalloenzyme. A simple biological role for nickel. J Am Chem Soc., 97:4131-4133.

[43] Bertrand D, Wolf A., (1967). Nickel, a dynamic trace element for higher plants. C R Acad Sci., 265:1053-1055.

[44] Brady NC, (2002). The nature and properties of soils. Prentice-Hall of India Private Limited, Inc, Upper Saddle River, p 621.

[45] Mortved. J.J., (1991). Micronutrient fertilizer technology. In J.J. Mortved, F.R. Cox, L.M. Shuman, \& R. M. Welch (Eds.), Micronutrients in agriculture (SSSA Book Series), Vol.4. PP. 89-112. Madison. W1: Soil Science Society of America. https://doi.org/10.2136/sssabookser4.2ed.c14.

[46] Lal, R., (2006). Enhancing Crop Yields in the Developing Countries through Restoration of the Soil Organic Carbon Pool in Agricultural Lands. Land Degradation \& Development, 17, 197-207. https://doi.org/10.1002/ldr.696.

[47] Matsumoto, T. and Yamano, T., (2009). Soil Fertility, Fertilizer, and the Maize Green Revolution in East Africa. Policy Working Paper, WPS5158, Japan's National Graduate Institute for Policy Studies and the World Bank Development Research Group Agriculture and Rural Development.

[48] Alimi, T., Ajewole, O.C., Awosola, O. and Idowu, E.O., (2007). Organic and Inorganic Fertilizer for Vegetable Production under Tropical Conditions. Journal of Agricultural and Rural Development, 1, 120-136.

[49] Abedi, T., Alemzadeh, A. and Kazemeini, S., (2010). Effect of Organic and Inorganic Fertilizers on Grain Yield and Protein Banding Pattern of Wheat. Australian Journal of Crop Science, 4, 384-389.

[50] Roba, T.B., (2018). Review on: The Effect of Mixing Organic and Inorganic Fertilizer on Productivity and Soil Fertility. Open Access Library Journal, 5: e4618. https://doi.org/10.4236/oalib.1104618.

[51] Stout, B. A., (1979). "Energy for World Agriculture.” Food and Agriculture Organizations of the United Nations, Rome.

[52] https://www.ipni.net/specifics-en.

[53] Annual Report, (2019-20). Department of Agricultural Research and Education, Ministry of Agriculture and Farmers Welfare, Government of India, Indian Council of Agricultural Research, New Delhi.

[54] Loura, Deepak \& Kumar, Suresh \& Kumar, Pawan \&Soni, Sunil \& Rathore, Akshit\&Dhankar, Amit., (2020). Response of Different Organic and Inorganic Sources of Nutrients on Growth and Yield of Wheat (Triticum aestivum L.).
[55] Ouni, Y., Lakhdar, A., Scelza, R., Scotti, R., Abdelly, C., Barhoumi, Z., Rao, M.A., (2013). Effects of two composts and two types of grass on microbial biomass and biological activity in salt-affected soil. Ecol. Eng., 60, 363-369.

[56] Garcia-Gil, J.C., Plaza, C., Soler-Rovira, P., Polo, A., (2000). Long-term effects of municipal solid waste compost application on soil enzyme activities and microbial biomass. Soil Biol. Biochem, 32, 1907-1913.

[57] IARI. Annual Report, (2005-2006). Indian Agricultural Research Institute, New Delhi - 110 012, India.

[58] Kharub, A.S., Chauhan, D.S., Sharma, R.K., Chhokar, R.S. and Tripathi, S.C., (2003).Diversification of rice-wheat system for improving soil fertility and productivity. Indian Journal of Agronomy, 48(3): 149 -152. 